
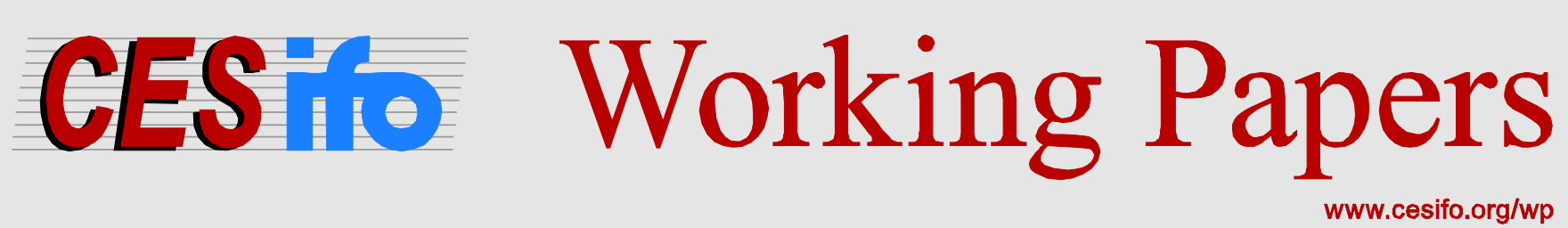

\title{
How Should Pensions be Taxed? Theoretical Considerations and the Scandinavian Experience
}

\author{
Torben M. Andersen
}

CESIFO WORKING PAPER NO. 5660

CATEgORY 1: PUBlic FinANCE

DECEMBER 2015

An electronic version of the paper may be downloaded

- from the SSRN website: Www.SSRN.com

- from the RePEc website: Www.RePEc.org

- from the CESifo website: www.CESifo-group.org/wp 


\title{
How Should Pensions be Taxed? Theoretical Considerations and the Scandinavian Experience
}

\begin{abstract}
How should pensions be taxed? In many cases pension savings are usually taxed more leniently than other forms of savings. What is the rationale for this? And are those concerns best targeted via taxation or mandatory pension savings? These issues are discussed with outset in the experience of the Scandinavian countries (Denmark and Sweden). These countries are also interesting because they have implemented a dual income taxation scheme; i.e. they pursue an ETT-taxation regime vis a vis pensions. It is argued that the incentive structure related to pension savings and retirement can not be seen independently from how private pensions (and savings more generally) affect public pensions via meanstesting. The effective rates of taxation may thus differ significantly from the nominal rates. For Denmark and Sweden it is shown that the effective tax rates on pension savings can be rather high, and for low/medium income close to $100 \%$.
\end{abstract}

JEL-Codes: H200.

Keywords: pensions, taxation, means-testing, distribution, effective tax rates.

Torben M. Andersen

Department of Economics and

Business Economics

Aarhus University

Fuglesangs Allé 4

Denmark - 8210 Aarhus V

tandersen@econ.au.dk

November 2015

Paper presented at the CEPAR-CESifo Workshop on "Taxations of pensions", Munich, September 3 and 4, 2015. 


\section{Introduction}

It is a primary savings motive to cater for consumption possibilities post retirement. Any type of savings will in principle serve this purpose with proper account taken of returns and risks. However, pension savings often have a particular status including more lenient taxation or subsidies than other forms of savings. Many countries also have mandatory elements in pension savings. This raises the fundamental question: What is the rationale for differential treatment of pension savings relative to other forms of savings?

The taxation of pension savings is a specific question within the more general area of capital income taxation. There is a vast literature on whether capital income should be taxed; see e.g. Diamond (2009) for a discussion. The focus here is not a normative analysis of the optimal taxation of capital income, but a positive analysis of the relevant tax wedges arising from taxation and how they may be of importance for pension savings and retirement. The starting point is the empirical fact that capital income is taxed, and the prime question is whether taxation of pension savings should be different than for other forms of savings and hence capital income.

The purpose of this paper is twofold, namely, both to discuss some of the principle issues in the taxation of pensions and to consider the specific way of taxing pension savings in the Nordic countries (Denmark and Sweden). Besides the interest in the Nordic countries for their own sake, they are interesting both for having adopted a so-called dual income tax system and their extended welfare models. The welfare state perspective is interesting since the taxation of private savings and its interaction with public pension schemes raise crucial questions on incentives, insurance and redistribution. Denmark and Sweden are moreover among the few countries having a so-called ETT scheme for pension savings. However, the two countries differ significantly in the design of the pension systems, cf. below.

The Nordic countries ${ }^{1}$ have been front-runners in applying the dual income tax system; that is, a system with a separation between labour income and capital income taxation, where the former is progressively taxed and the latter is proportionally taxed. One key argument in support of this tax system is that it reconciles low capital income tax rates to avoid capital mobility with the possibility of maintaining higher and more progressive labour income tax rates; cf. Sørensen (2010).

While the Nordic countries are usually clustered together under the heading of the Nordic welfare model, it is important to point out that the pension schemes are very different across the Nordic countries; see e.g. Andersen et al. (2014). In Denmark the pension system is organized around funded occupational pension funds along with PAYG-public pensions, while Sweden has adopted a so-called notionally defined pension scheme which largely is a PAYG-based system in which pensions stand in relation to labour income earned during the

\footnotetext{
${ }^{1}$ The dual income tax system is not applied purely in Denmark since positive net-capital income above a threshold level is taxed on par with labour income. Finland has also recently introduced a moderate progressive element in capital income taxation.
} 
work career. Norway and Finland have pension systems including both PAYGpension and funded pensions.

These differences underline a more general point concerning the Nordic countries. Even though they share some overriding objectives reflected in extended welfare states, the specific way of designing specific policies differs in significant ways. This points to the overall objectives and packaging of policies and institutions as being important rather than the specific policy instruments applied.

The paper is organized as follows: Section 2 starts out discussing some principal aspects related to the tax treatment of pensions, and Section 3 presents and discusses various taxation regimes. The specificities of pension taxation in Denmark and Sweden are covered in Section 4 and 5, respectively. A few concluding remarks are given in Section 6, and an appendix contains some technical material.

\section{Principle aspects}

The basic question is whether pension savings and its return should be taxed on par with other forms of capital income, or whether there are reasons for a different treatment? The answer to this question depends crucially on whether private savings are adequate from a social perspective, or whether agents for some reasons tend to undersave.

The pension economics literature features "present bias" as a reason why agents do not attach sufficient weight to future consumption and therefore tend to save too little. Present-biased decisions can either result from too high subjective time preferences (myopia) or self-control problems. A straightforward case is myopia where the decisions are made under a higher subjective discount rate than that associated with true preferences; see e.g. Feldstein and Leibman (2002) and Pestieau and Cremer (2011). A particular form of this is so-called hyperbolic discounting where all future periods are given insufficient weight relative to the present ${ }^{2}$; see Laibson (1996). An alternative approach assumes that agents suffer from self-control problems and therefore are tempted to increase current consumption at the cost of reduced future consumption; see e.g. StAmant and Garon (2014). For the present purpose these different approaches are essentially observationally equivalent in predicting an inoptimal low level of voluntary pension savings.

Insufficient voluntary savings for pension motivates intervention ${ }^{3}$, but which form should this intervention take? Should incentives to save be strengthened via the taxation system, or should pension saving (up to some level) be mandatory? Both forms of intervention are used by most OECD countries (OECD

\footnotetext{
${ }^{2}$ Time inconsistency arises because there is a difference in the marginal rate of substitution between period $t$ and $t+1$ and that between $t+1$ and $t+2$ (and all future periods). With the passage of time agents change behaviour relative to what is planned in period $t$.

${ }^{3}$ This involves a question of paternalism in the sense that the policy maker "knows better" what is in the true interest of the individual.
} 
$(2013))^{4}$.

Finding a rationale for intervention in savings decisions does not settle the appropriate form of intervention. This is an issue which the literature on pension economics has not considered in much detail. A number of studies argue why mandatory pension savings can be welfare improving. Even if public pensions of the PAYG type are return dominated in a dynamically efficient economy, they may be associated with welfare gains if agents are sufficiently present-biased ${ }^{5}$. Mandated pension saving in a funded scheme is in general justified if there is some present bias; see Andersen and Bhattacharya (2011, 2015). Krusell et al. (2010) analyse an interest rate subsidy in the case of households suffering from self-control problems and find that it can be welfare improving.

But what mode of intervention (price vs. quantity control) should be used? If the motivation for intervention is present-biased preferences, it may be argued that interest rate subsidies are imprecisely targeted since such subsidies are also available (or pre-dominantly used by) to individuals not suffering from presentbiased preferences and therefore saving adequately. This implies a deadweight loss from this form of intervention ${ }^{6}$. This problem can partly be circumvented by setting a cap for the interest subsidy (e.g. maximum annual contribution for which the subsidy applies). A mandatory savings level would have no or only small effects on those who do not suffer from present-biased preferences and hence save enough from a social point of view. For individuals suffering from a present bias, the mandatory savings will have effects on their net savings ${ }^{7}$. In this sense, pension savings is better targeted via mandated saving than interest rate subsidies.

An important caveat should be added concerning mandatory pension savings. Mandatory pension savings does not eliminate incentive questions. The question is whether mandated savings contributions are considered $\operatorname{atax}^{8}$. First, assume that the return on voluntary and mandatory savings is the same, then mandatory savings increases net savings only if the latter is driven to zero ${ }^{9}$. In

\footnotetext{
${ }^{4} \mathrm{PAYG}$ pensions are by nature mandatory. Pillar II occupational pension schemes are also usually mandatory at the individual level.

${ }^{5}$ If mandatory and voluntary savings offer the same rate of return, mandatory pension savings will on a one-to-one basis crowd-out voluntary savings. Mandatory savings will thus only increase net-savings if voluntary savings is driven to zero (and borrowing is either ruled out or is possible only at an interest rate higher than the savings rate); see Andersen and Bhattacharya (2015).

${ }^{6}$ If present-biased preferences are related to socio-economic factors such that there is a lower prevalence of present bias among high income groups, an interest rate subsidy may be regressive.

${ }^{7}$ Evidence for Denmark points to relatively low crowding out (25-30\%) of voluntary savings; see Arnberg and Barslund (2012) and Chetty et al. (2014).

${ }^{8}$ If mandated (occupational) pensions are the outcome of negotiations between the social partners, the taxation of pension savings may affect the negotiated contribution rates.

${ }^{9}$ Present-biased households try to evade the mandatory savings by reducing voluntary savings. In the case of a borrowing constraint, the crowding out continues until voluntary savings is driven to a corner; see Andersen and Bhattacharya (2011). Increasing mandatory savings thus reduces present consumption which, as seen from the household perspective, has a higher marginal utility than discounted future consumption, and hence mandatory savings has a distortion cost, although lower than general income taxation.
} 
this case mandatory savings affects labour supply. Hence, the effective taxation of pension savings matters and may affect labour supply both along the intensive and the extensive margin, see e.g. Kaplow (2015).

The argument for intervention in pension savings decisions is intimately related to constraints on the possibilities for claiming these savings. The constraint is that the savings is available only after reaching a certain age or upon retirement ${ }^{10}$ Moreover, there may be constraints on tax favoured forms of pension benefits. Pension benefits can be structured as: (i) a lump-sum instalment (capital pension), (ii) a rate-pension (payments of a given amount, a fixed number of years, say 10 years) or (iii) a life-time annuity. The trust of the argument for intervention is that agents tend to front-load consumption leaving insufficient consumption possibilities as old. This gives an argument why the major part of mandated pensions should be in the form of annuities ${ }^{11}$ to ensure consumption throughout life. This is related to the so-called annuity paradox according to which individuals tend to place a too low share of savings in annuities; see e.g. Davidoff et al. (2005)). This may reflect a present bias, a failure to understand annuity products, or market failures (e.g. imperfect competition) in annuities markets. A requirement that subsidized or mandatory pension savings predominantly apply to life-annuities may thus also overcome insufficient use of annuities ${ }^{12}$

In a welfare state a particular moral hazard problem may arise. Welfare arrangements like public pensions, health, housing subsidies etc. are implicit life-annuities in the sense that eligibility applies throughout life. Hence, if savings is not in the form of life-annuities, there is an asymmetric risk sharing between the individual/heirs and the welfare state. If the individual passes away early, the heirs would benefit from the bequest (if savings is not in annuities), but if the individual lives long, the welfare state is automatically stepping in to provide support. Hence, extended welfare arrangements may be a separate reason why there is "insufficient" demand for life-annuities. It should be added that there are arguments why less than $100 \%$ of mandated pension savings should be paid out as life-annuities. Consumption needs may be age dependent and a lump-sum payment upon retirement may provide a precautionary buffer.

\section{Pension taxation regimes and tax wedges}

Pension schemes have three basic dimensions: Contributions, returns and benefits. Any of these dimensions can be subject to taxation ( $\mathrm{T}$ ) or exempt from taxation $(\mathrm{E})$. This leaves 8 possible pension taxation regimes $\{(\mathrm{E}, \mathrm{E}, \mathrm{E})$,

\footnotetext{
${ }^{10}$ Eventual withdrawal is possible a few years earlier than the statutory retirement age. Usually there are penalties for earlier withdrawal, but also exceptions in case of e.g. critical illness.

${ }^{11} \mathrm{An}$ annuity is not uniquely defined, the payment may be nominal or indexed, and there may be contingencies for changes in longevity at the cohort level.

${ }^{12}$ As an example, occupational pensions may simultaneously mandate agents to save for pensions and create annuities within the risk-class defined by the members; i.e. a double inefficiency is addressed.
} 
T,E,E)......(E,T,T), (T,T,T)\}; see Yoo and de Serres (2004). Adding indirect forms of taxation via possible means-testing of public pensions, cf. below, there are 16 possible regimes when including both explicit taxation and implicit taxation via means-testing.

In comparing these regimes there are two key questions: i) Does the timing of tax payments have a separate role from that of tax rates? and ii) what are the tax wedges affecting saving and retirement decisions? To answer these questions it is useful to consider a standard life-cycle model of consumption and work (both along the intensive and extensive margin), cf. Appendix. It allows both for the explicit forms of taxation but also means-testing to identify the key margins or tax wedges of importance for savings and work. It also allows for present-biased preferences via the subjective discount rate (myopia) ${ }^{13}$.

In general (capturing all possible regimes outlined above) the individual faces the following tax-pension scheme: Labour income is taxed at the rate $\tau_{y}$, contributions to funded pension schemes are deductible in labour income at the rate $\tau_{d}$, while benefits from funded pensions are taxed at the rate $\tau_{p}$. Return on pension savings is taxed at the rate $\tau_{r}$. All tax rates belong to the interval $[0,1[$.

If $\tau_{d}=\tau_{y}$, it follows that contributions are fully exempted from taxation, if $\tau_{r}>0$, there is return taxation, and if $\tau_{p}>0$, benefits are taxed. When retired the individual is entitled to a public pension $b$ which is means-tested against private pensions (wealth) at the tapering rate $m \in[0,1[$.

The standard model identifies the following retention rates or tax wedges, cf. Appendix:

- Work along the intensive margin:

$$
\left(1-\tau_{y}\right)
$$

- Consumption profile within working and retirement periods:

$$
\left(1-\tau_{r}\right)
$$

- Consumption when working and retired, and retirement decision:

$$
\omega \equiv \frac{(1-m)\left(1-\tau_{s}\right)}{\left(1-\tau_{d}\right)}
$$

Several points are worth making. First, there is an important equivalence result $^{14}$. A (T,E/T,E)-system has $\tau^{d}=0, \tau_{r} \geq 0$ and $\tau^{s}=0$, while an $(\mathrm{E}, \mathrm{E} / \mathrm{T}, \mathrm{T})$ scheme has $\tau^{d}=\tau_{y}, \tau_{r} \geq 0$ and $\tau^{s}=\tau_{y}$. Hence, in either case - for the same tax rates $\tau_{y}$ and $\tau_{r}$ - the tax wedges are the same, and hence behaviour is the same in the two regimes. This implies that the present value of taxes paid is the

\footnotetext{
${ }^{13}$ The importance of myopia materializes in normative assessments of the adequacy of individually decided savings levels and retirement ages.

${ }^{14}$ See Yoo and de Serres (2004) present some examples illustrating this.
} 
same, and hence the allocation between current and future consumption is also the same. Hence, for the same tax rates, the timing of tax payments does not matter for behaviour ${ }^{15}$. It is a corollary that postponement of taxation as in a $(\mathrm{T}, \mathrm{E} / \mathrm{T}, \mathrm{T})$ regime does not favour pension saving when agents do not suffer from tax illusion, see below.

In the case where $\tau_{d}=\tau_{y}$ and $\tau_{s}<\tau_{y}$, there is a tax subsidy to pension saving $\left(\frac{\left(1-\tau_{s}\right)}{\left(1-\tau_{d}\right)}>1\right)$. This situation may arise in an $(\mathrm{E}, \mathrm{E} / \mathrm{T}, \mathrm{T})$ scheme if income taxation is progressive since most would have a higher income when working than when retired ${ }^{16}$ (implying $\tau_{s}<\tau_{y}$ ).

It is often argued that the time horizon matters for how pension savings is taxed. E.g. if the return is taxed more leniently than other forms of capital income, then clearly the value of the lower taxation is larger, the longer the investment period due to a compound return effect, see Appendix. This effect may also dominate the direct effect of taxation and means-testing. While these observations are correct, the tax distortions are ultimately determined by the terms explained above.

The equivalence result discussed above presumes rational behaviour ${ }^{17}$. A question is whether there is some tax-illusion in the sense that tax deductions are interpreted as tax rebates disregarding the latter taxation of the benefits. Advertisements by pension funds often emphasize the tax deduction without highlighting the latter taxation. Contributions into voluntary pension savings arrangements also tend to peak towards the end of the year, which may reflect attempts to reduce the tax payment ${ }^{18}$.

On the return taxation two points are worth noting. First, the tax is levied on the nominal return, and hence the effective taxation of the real return exceeds the tax rate on the nominal return. Secondly, annuities have a higher return via the insurance mechanism related to survival, and this "extra" return is not taxed when the return tax is levied on the market return.

One argument for an $(E, E / T, T)$ regime is the global income principle that all incomes are treated equally and therefore only the sum matters for the total tax payment. In the Scandinavian countries this principle is applied for all earned income and social transfers (including pensions). Accordingly all social transfers are gross amounts and taxable income. The key argument in support of this system is that it provides a better basis for redistribution (including progressive elements in taxation), and it is based on the premise that disposable income determines current consumption possibilities. Moreover, it allows the

\footnotetext{
${ }^{15}$ Statements to the opposite are often made, e.g. "The Commission supports this system of deferred taxation since contributions to pension funds diminish a person's ability to pay taxes and since it encourages citizens to save for their old age. In addition, it will help Member States to deal with the demographic time-bomb, as they will be collecting more tax revenues at a time when more elderly people may call on the State for care."

http://ec.europa.eu/taxation_customs/taxation/personal_tax/pensions/index_en.htm

${ }^{16}$ Tax deductibility of pension contribution when working can imply "inverse" means-testing by reducing tax rates when working since taxable income is reduced.

${ }^{17}$ Note that present-biased decision makers act rationally but based on a "biased" objective function.

${ }^{18}$ It may also reflect greater certainty about the earnings within the year.
} 
individual a possibility of smoothing marginal tax rates so as to make them more dependent on life-time income.

The choice of taxation scheme also raises issues in relation to portability and competition. In the $(E, E, T)$ this is no issue, but in any $(E / T, T, T)$ there is an issue both in relation to competition between pension product providers, but also portability of pensions in case of migration ${ }^{19}$. From a taxation point of view, there is a risk that taxation is evaded. Clearly both issues are related to EU-regulation and especially the single market. To illustrate this, consider the case of Denmark where the taxation of pensions was changed in 2007 to admit tax deductibility for contributions into a pension savings arrangement in any EU-country. This was done since the earlier principle of only allowing for deductibility for contributions into Danish pension arrangements was contested by the EU court. The foreign pension fund shall, however, be approved by the Danish tax authorities, and the arrangement shall correspond to Danish pension arrangements. Moreover, the fund shall agree to pay the tax on both the return and benefit payments to the Danish tax authorities. Only six foreign pension funds are approved so far. There are special rules for migrant workers who, within a period of up to 60 months, can use a foreign pension fund with full deductibility for contributions, no return taxation and the benefits (if received in a foreign country) are not taxable in Denmark .

\section{Means-testing}

The role of means-testing is already seen from the tax wedges outlined above. It is thus crucial to consider the implicit taxation via means-testing on par with explicit taxation to assess the overall incentive structure. In general means-testing can involve different treatments of various types of assets and incomes, but here a very stylized setting is considered as a basis for discussing the implications ${ }^{20}$.

The overall division of labour in pension schemes is that public pensions ${ }^{21}$ are targeted distribution objectives while private (funded) pensions target the consumption smoothing objective. While this logic appears clear, the actual design is somewhat more complicated since it is not possible to separate the different roles or objectives completely. In particular the distribution objective cannot be separated from the consumption smoothing objective. The problem is that it is not possible to combine the two without creating incentive problems. To see this, consider the basic question of how to design public pensions such

\footnotetext{
${ }^{19}$ The Faroe Islands recently changed regime to a $(T, T, E)$ to avoid loss of tax revenue due to emigration of pensioners. Greenland is considering a similar move.
}

\footnotetext{
${ }^{20}$ In general, means-testing implies a non-convex budget set, which complicates the analysis considerably, and which may imply bunching (many individuals being at the corner); see e.g. Fehr and Uhde (2015.

${ }^{21}$ This is most clearly seen in the case of a flat rate pension. Even in systems where pensions in some way are related to some measure of life-time income, there is some "guarantee pension" for low income groups for distributional reasons, see e.g. below for Sweden.
} 
that they are targeted to the economically weakest pensioners. This could be in the form of stipulating a minimum guaranteed pension ensured for all old. If the public pension system is designed to ensure this, it will compensate for any pension below this level to ensure that the individual meets the minimum requirement, cf. Figure 1a. However, the flip-side of this is that any increase in private pensions (as long as it is below the minimum level) effectively is taxed at $100 \%$ (higher private pensions in this interval do not increase the total pension but only its composition between private and public pensions). As a response to this, the public pension may be phased out more gradually (an off-set rate or taper rate below 100\%) as is illustrated in Figure 1b. This implies a lower implicit tax rate, which may be conducive for savings and later retirement. However, this is achieved at the costs of higher public expenditures on pensions, which in turn have to be financed by (distortionary) taxes. A flat rate pension universal for all is the limiting case where all receive the same public pension. Clearly, this leaves a zero implicit tax rate in the pension system, but higher public expenditures and thus higher explicit tax rates.

\section{Figure 1: Public pensions, distribution and means-testing}

(a) $100 \%$ off-set against private pensions

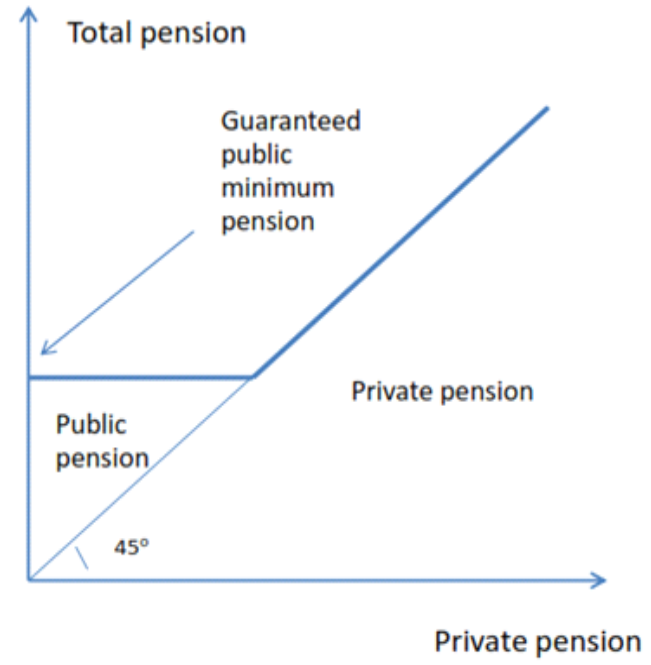

(b) Partial off-set against private pensions

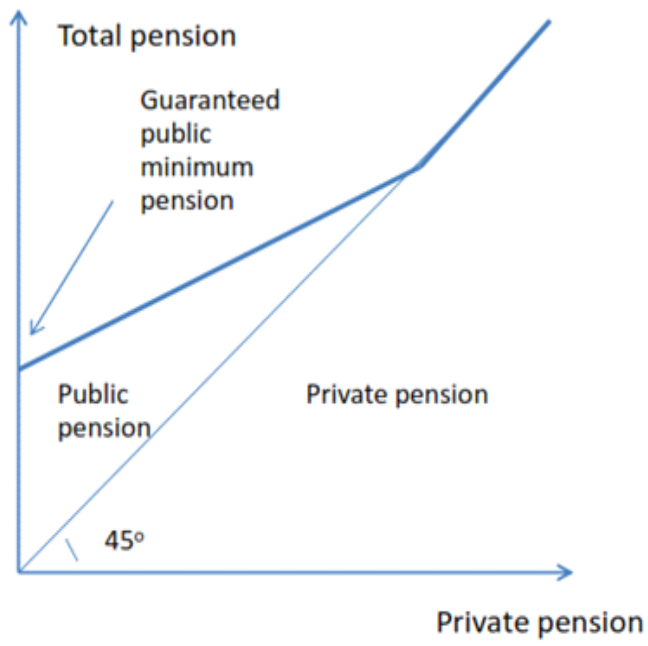

Since means-testing in most cases implies a threshold above which no pension is received ${ }^{22}$, it follows that the effect on the tax wedge arises for low/medium levels of income (pensions). For higher levels of income(pensions) a marginal increase in income (pension) has no effect on public pensions received, and the tax wedge is thus lower; i.e. a regressive bias arises from the combined effect of

\footnotetext{
${ }^{22}$ There may also be a threshold such that contributions above a certain level do not imply higher pensions; i.e. the contribution rate at this kink becomes a tax, see below on Sweden.
} 
taxes and means-testing ${ }^{23}$.

The discussion above points to the possible adverse incentive effects of the interplay between public and private pensions via means-testing of the latter (and taxation in general). However, this also has an insurance effect. All changes in private pensions beyond individual control, like involuntary unemployment or variations in the return on pension savings, are shared/absorbed via public pensions ${ }^{24}$. Since means-testing applies for relatively low incomes/pensions, there is an asymmetry in the insurance mechanism. Households ending up with low private pensions receive more from the public system. In case of a higher private pension, means-testing ceases at some point, implying that further increases in private pensions are to the benefit of the individual (low effective tax). The implicit insurance created via means-testing and taxation is thus mainly an insurance against downside risks.

\section{Taxation of pensions and capital income in Denmark and Sweden}

In this section we turn to a discussion of taxation of pensions and capital income in Denmark and Sweden. The two countries are similar in having an extended welfare state and following an $(\mathrm{E}, \mathrm{T}, \mathrm{T})$ taxation regime. However, the two countries differ significantly in the design of the pension system.

\subsection{Denmark $^{25}$}

The public pension includes a basic amount (flat-rate pension) and means-tested supplements (residence requirement). Furthermore, there are a number of agedependent supplements. These pension entitlements are of the defined benefit type, and tax financed. Public pensions are indexed to wages.

By law all wage earners and recipients of transfer income contribute to the supplementary labour market pension (ATP). It is a defined contribution scheme to which all contribute the same monthly amount (depending on working hours). The contribution rates are relatively small, and therefore this scheme cannot in itself ensure sufficiently high replacement rates.

Labour market pensions are agreed upon as part of an employment relationship or through collective agreements between the social partners. The development of labour market pensions took off in 1989-91, and the arrangements have subsequently been extended to a large part of the labour market, and contribution rates have until recently been increasing. Today contribution rates vary between $12 \%$ and $18 \%$, with rates tending to be higher for high income groups.

\footnotetext{
${ }^{23}$ Fehr and Uhde (2015) show how means-testing creates a kink making the budget set convex.

${ }^{24}$ The Money and Pension Panel Expert Group (2012) presents a number of cases for Denmark showing an implicit insurance effect in the sense that total pensions vary less than private pensions in case of various events.

${ }^{25}$ See also Andersen (2015a,b) and Pensionskommissionen (2015).
} 
Private pension savings comprise other forms of savings (voluntary savings) as well as savings in pension savings schemes in banks and insurance companies (the return is taxed more leniently, but the funds are tied to retirement).

Figure 2 provides an overview of the pension system, and shows the interaction between public and private pensions (means-testing).

Figure 2: Structure of public pensions, Denmark 2015

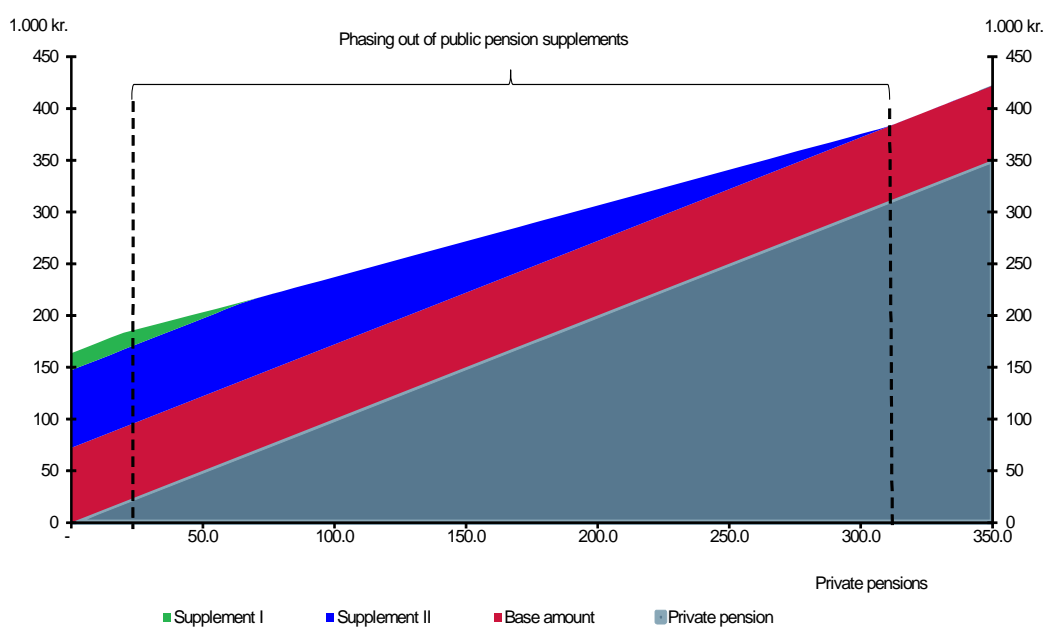

Note: The figure gives a stylized illustration of the public pension system in Denmark 2015. Other supplements to the old (including housing) than the direct pension supplements (Supplement I: Pensionstillæg; Supplement II: Særlig pensionsydelse) are disregarded. Pensions are taxable income. 1 DKK is (July 2015) approx. $0.15 \$$.

Source: Pensionskommissionen (2015).

Statutory ages in the pension system (for public pensions, for early retirement, and age limits for payment of funds from pension schemes) are established by legislation. Recent reforms - the welfare reform from 2006 and the retirement reform from 2011 - will increase these ages considerably to cope with an ageing population. The first element of the reforms is discrete increases in the early retirement age from 60 to 62 years over the period 2014-17, shortening the early retirement period from five to three years over the years 2018-19 and 2022-23, implying an early retirement age of 64 in 2023, and increasing the pension age from 65 to 67 years over the period 2019-22. The second element is an indexation of the early retirement age and pension age to the development in life expectancy at the age of 60 in order to target the expected pension period to 14.5 years (17.5 including early retirement) in the long run (currently about18.5/23.5 years).

The overall structure of pension taxation in Denmark is summarized in Table 1. The most important types of pensions - life annuities and so-called rate pensions - are of the (E,T,T)-type and they are included in the base for means testing. However, for the rate pension there is a cap on the annual deduction. A more recent scheme - entitled "Old age pension" is of the (T,T,E)-type and 
is not included in the base for means-testing (there is also a cap on the annual contribution). For all types the return is taxed at the rate $15.3 \%$.

Table 1: Taxation of pensions, Denmark, 2015

\begin{tabular}{llllll}
\hline & Limit, DKK & Deduction & Return tax & Benefits & Means testing \\
\hline \hline Life annuity & None & Marginal tax & $15.3 \%$ & Marginal tax & Yes \\
\hline Rate pension & 51.700 & Marginal tax & $15.3 \%$ & Marginal tax & Yes \\
\hline Old age pension & 28.600 & No & $15.3 \%$ & No & No \\
\hline
\end{tabular}

Note: Contributions to a so-called capital pension are since 2013 no longer tax deductible, and inpayments have ceased. Applies to 2015. For old-age pension (alderspension) there is no means-testing if the outpayment is a lump-sum payment.

Source: www.skm.dk.

As noted above the tax value of the tax deduction for contributions $\left(\tau_{d}\right)$ may differ from that of the taxation of pension benefits $\left(\tau_{s}\right)$ due to progressive elements in the taxation system. Figure 3 illustrates this by giving the tax rates for contributions and outpayments respectively. The difference arises because the earned income tax only applies when working and thus for the tax value of pension contributions. Note that an earned income tax credit tends to reduce the incentive to save for pensions. The other aspect is that some may have a tax value of the deduction when working at about $52 \%$ and a tax of about $38 \%$ on the benefit, and the difference leaves a tax incentive to pension savings for groups with high earnings when working. 
Figure 3: Tax rates applying to pension contributions and benefits, 2015

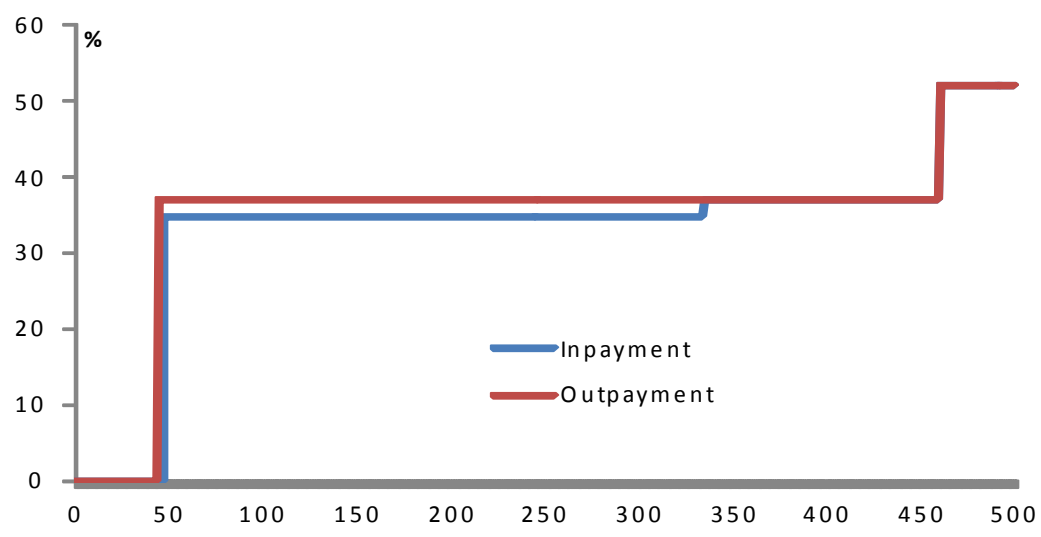

Note: Tax values computed for an average municipal tax of $24.9 \%$, excl. church tax. Labour market contribution and employment deduction taken into account, 2015 values and rates.

The means-testing arises since public pensions include a base amount and means-tested supplements. In addition there are means-tested supplements for housing and other needs.

Figure 4: Average replacement rates at the age of 66 across income deciles, 2012

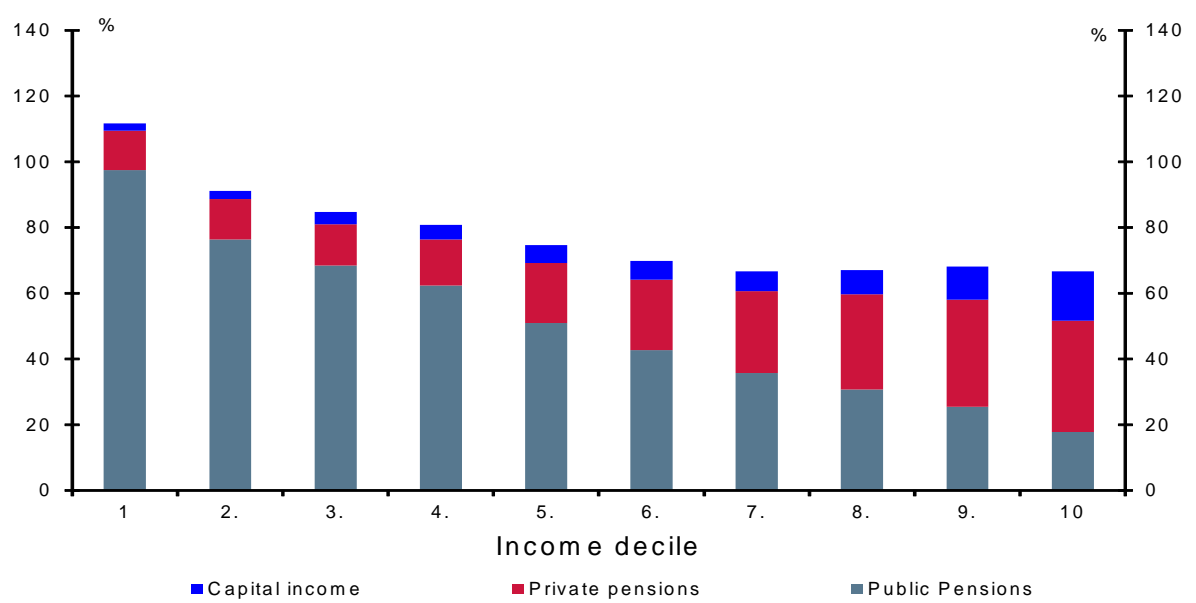

Note: Replacement rates are computed for individual disposable income at age 66 relative to the disposable income at age 55-57 (also the incomes used for the construction of income deciles). The disposable income at age 55-57 is adjusted to 2012-level by use of the index for the general wage development. Among the age group 66, only persons without market income are included.

Source: Pensionskommissionen (2015). 
Figure 4 shows the replacement rates across the income distribution and their composition. It is seen that the replacements rates are high for low income groups reflecting the generosity of the public pensions (basically ensuring that low income individuals never experience an income drop upon retirement; hence the replacement rates close to $100 \%$ ). The composition of the replacement rate is also seen to vary across incomes, reflecting that public pensions via the meanstesting is targeted to low and medium income groups. It is an implication of the means-testing that poverty among pensioners is very rare in Denmark, cf. Figure 5 .

Figure 5: Share of persons above age 65 in the low income group 2012

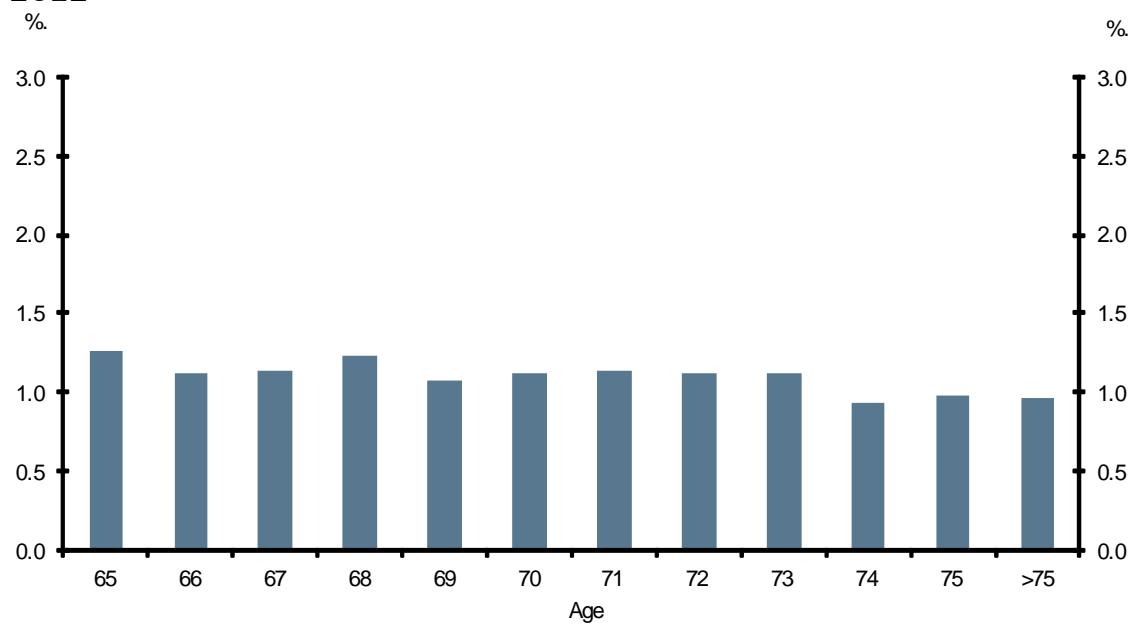

Note: The low income group is defined by having a disposable income below $50 \%$ of the median income for the entire population.

Source: Pensionskommissionen (2015).

Due to the many details in both the taxation and the pension scheme, it is difficult to summarize the effective tax rates on pension savings and retirement decisions in a few numbers. Figure 6 illustrates the effective tax rates on pension savings for a single person living in a rented apartment. Two points are worth observing. First, low/middle income groups face higher effective tax rates than high income groups. The reason is the means-testing as explained above. Secondly, the complexity and implied lack of transparency are illustrated by the huge variations in effective tax rates. 
Figure 6: Effective tax rates on pension savings, 2015

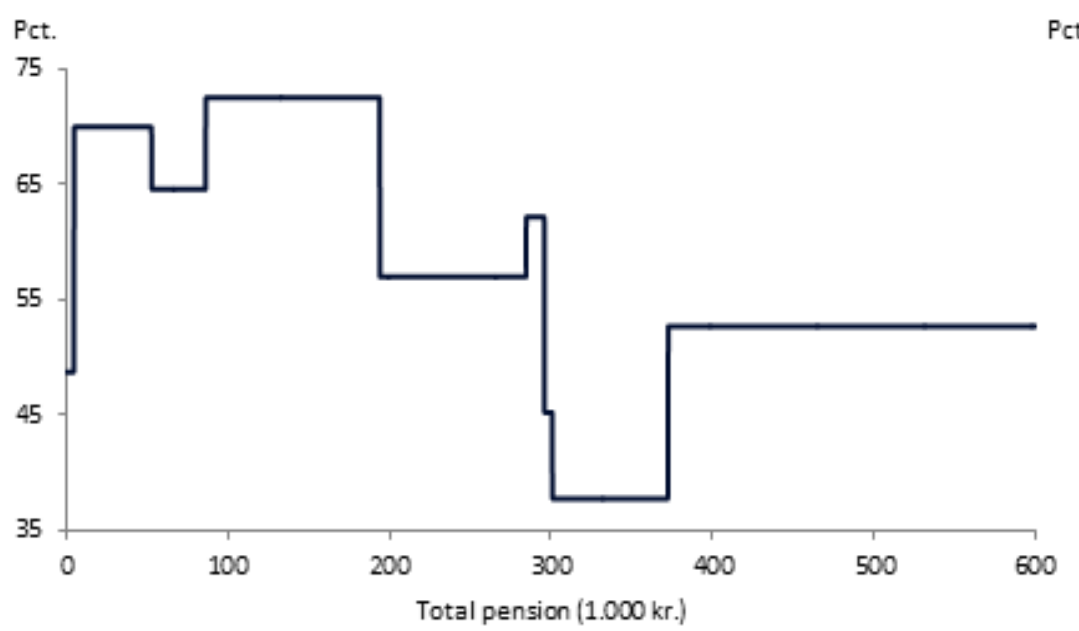

Note: Stylized case for a pensioner being single and living in a rented accommodation and thus receiving means-tested rent subsidy.

Source: Pensionskommissionen (2015).

The current system has very different rates of taxation on the return from different types of savings, cf. Figure 7 . This is problematic since it distorts asset allocation. The lower taxation of the return on pension savings is motivated by these savings being tied for release only when retired. The favourable taxation of housing is partly related to a nominal freeze of property taxes since 2002 .

A particular question is whether the tax structure provides incentives to socalled balance expansion for households. A person contributing to a pension saving (with a return tax of $15.3 \%$ ) and at the same time borrowing (with interest rates being deductible at a rate of 25-33\%) effectively receives a tax subsidy by expanding the balance. Denmark stands out by having households with a high gross debt ratio, although the average household is a net-creditor. Further, a persistent surplus on the current account also indicates that Denmark does not have a general savings problem. However, the liquidity of assets and liabilities is very different, and this may create a systemic risk factor of implications for macroeconomic stability. It may also be questioned why the tax system should give incentives in this direction. 
Figure 7: Tax rates on different types of savings, Denmark 2015

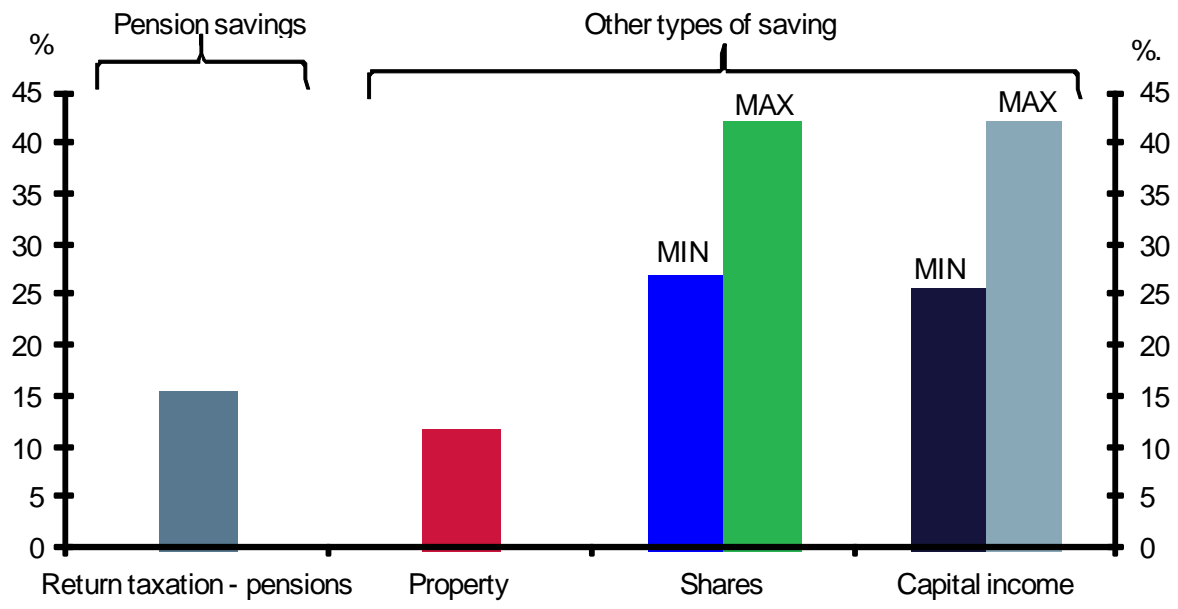

Source: Pensionskommissionen (2015).

\subsection{Sweden}

The Swedish Pension system was radically reformed in the 1990s with effect from 1999; see e.g. Palmer (2000) and Pensionsmyndigheten (2011, 2014). The public system has three elements: the guarantee pension, the income pension and the premium pension. The guarantee pension is tax financed, and the other two financed by contributions, cf. below.

In addition to the public schemes, occupational pensions are common (about $80 \%$ of workers). There are four pension funds, and as an example for the SAF$\mathrm{LO}$ area the contribution rate is $4.5 \%$ for incomes below some threshold ( 7.5 prisbasbelopp, approx. 335,000 SEK in 2015) and 30\% for incomes above this level.

For the income and premium pension the contribution rate is $18.5 \%$ of earnings, which is split between $16 \%$ for the income pension and $2.5 \%$ for the premium pension. The contribution rate has an employer and employee component. The premium pension is an individualized defined contribution system and thus fully funded. The income pension scheme is a PAYG scheme termed a notional defined contribution scheme.

The income base on which pension contributions are levied is earned income (also for self-employed based on tax declared income), social transfers, unemployment benefits etc. There is even an imputed income in case of child care (for children below the age of four) and education (post high-school) with contributions financed by the state. Pension contributions are made for incomes above a certain threshold (0.423 indkomstbasbelopp, approx. 19,000 SEK in 2015)) and some upper income limit (7.5 indkomstbasbelopp, approx. 436,000 SEK in 2015). For income above that level employers still pay contributions, but they are not credited to the individual accounts, but to the state (i.e. the 
contribution is effectively a tax). The core of the pension system is the notional defined contribution scheme implying that pensions are dependent on life-time earnings. Pensions are actuarially adjusted to the retirement age and longevity (for the cohort to which the individual belongs). There is a minimum age for eligibility for the guaranteed pension (65 years) and for withdrawal of income pensions (63 years).

The Swedish taxation regime is as the Danish an ETT scheme. The key elements are summarized in Table 1.

Table 1: Taxation of pensions, Sweden, 2015

\begin{tabular}{llllll}
\hline & Limit, SEK & Deduction & Return tax & Benefits & Means-testing \\
\hline \hline Individual pension saving & 1,800 & Marginal tax & $15 \%$ & Marginal tax & Yes \\
\hline Occupational private & $35 \%$ of income, & Marginal tax & $15 \%$ & Marginal tax & Yes \\
pensions & Max 445,000 SEK & & & & \\
\hline
\end{tabular}

Note: The max for individual savings has been reduced in recent years.

Source: www.skatteverket.se

The return $\operatorname{tax}^{26}$ has as the tax base the imputed return given as the average rate of return on government borrowing in the previous year times net assets (assets less financial debt). Since the government borrowing rate is typically lower than the rate of return on pension funds, the effective tax rate is below $15 \%$. Other types of capital income are taxed at the rate $30 \%$, though $27 \%$ on insurance arrangements (kapitalförsäkringar).

Means-testing arises both via the design of the guarantee pension and other supplements (housing). Figure 8 shows the sum of guarantee and income pension. The guarantee pension is the floor of the system available from the age 65. The pension is means-tested against the income and premium pension, and there is a residence requirement (minimum 3 years, full amount requires 40 years of residence). For pension below a certain level (1.26 pbb (single)/ 1.14 pbb (married)) the taper rate is $100 \%$, and it is $48 \%$ in the interval up to an upper threshold, $3.07 / 2.72 \mathrm{pbb}^{27}$. The guaranteed pension is price indexed. In 2014 about $2 \%$ of those in the age group $65+$ receive the full guaranteed pension, and about $1 / 3$ receive some fraction of the full amount of the guaranteed pension.

\footnotetext{
${ }^{26}$ The return tax was introduced in the mid-80s due to exceptionally (unexpected) high real rates of return. However, a tax on the real return was not introduced, and after some temporary measure, the current system was implemented, and the return tax has been $15 \%$ since 1995; see Bergström et al. (2010).

${ }^{27}$ The lower threshold is $1.26 \mathrm{pbb}$ for single and $1.14 \mathrm{ppb}$ for married, and the upper threshold is $3.07 / 2.72 \mathrm{pbb}$, respectively.
} 
Figure 8: Guarantee and income pension, Sweden 2014

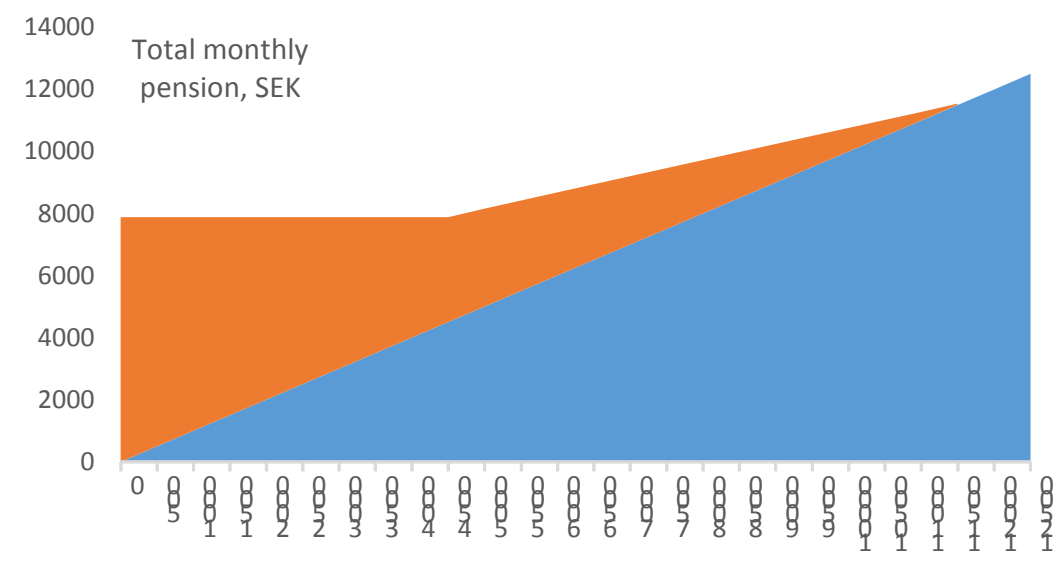

Monthly private pension

Source: Pensionsmyndigheten (2014).

In addition a housing supplement is available for pensioners (bostadstillägg för pensionärer). Eligibility applies from the age of 65 or above. It is required that the income and premium pension is claimed. The supplement applies for all forms of housing (rented, owner-occupied etc.). The supplement has an upper cap on housing expenses which can be subsidized. The supplement is $93 \%$ of housing costs less a reduction based on a weighted income-wealth concept. This income concept weighs public pensions, capital income and a wealth addition ( $15 \%$ of net wealth above some threshold, housing wealth not included) by $100 \%$, other forms of pensions by $80 \%$ and earned incomes (also as self-employed) by $50 \%$. A fraction of $62 \%$ of this composite income below a threshold, and income about this level by $50 \%$, is subtracted from housing costs to give the supplement.

The ultimate floor in the social safety net for elderly is a special transfer (äldreförsörjningsstöd) for people aged 65 with insufficient means. The transfer is means-tested and ensures that a minimum living standard can be maintained (the transfer is below the guaranteed pension).

The combined effect of the means-testing and the direct taxes is that the effective marginal tax rates can be rather high, especially in the case with low private pension, cf. Figure 9. The latter typically arises for low/medium income groups. As seen from the Figure, the effective tax rates are close to $100 \%$ for low levels of pensions falling to about $30 \%$ for high levels.

Both Denmark and Sweden thus share a similar structure for the effective taxation of pensions due to the combined effect of direct taxation and meanstested benefits to pensioners with low incomes. This brings forth the dilemma illustrated in Figure 1 of reconciling distributional goals with the incentive structure to save and to postpone retirement. 
Figure 9: Effective marginal tax rates, single pensioneer, with and without housing supplement

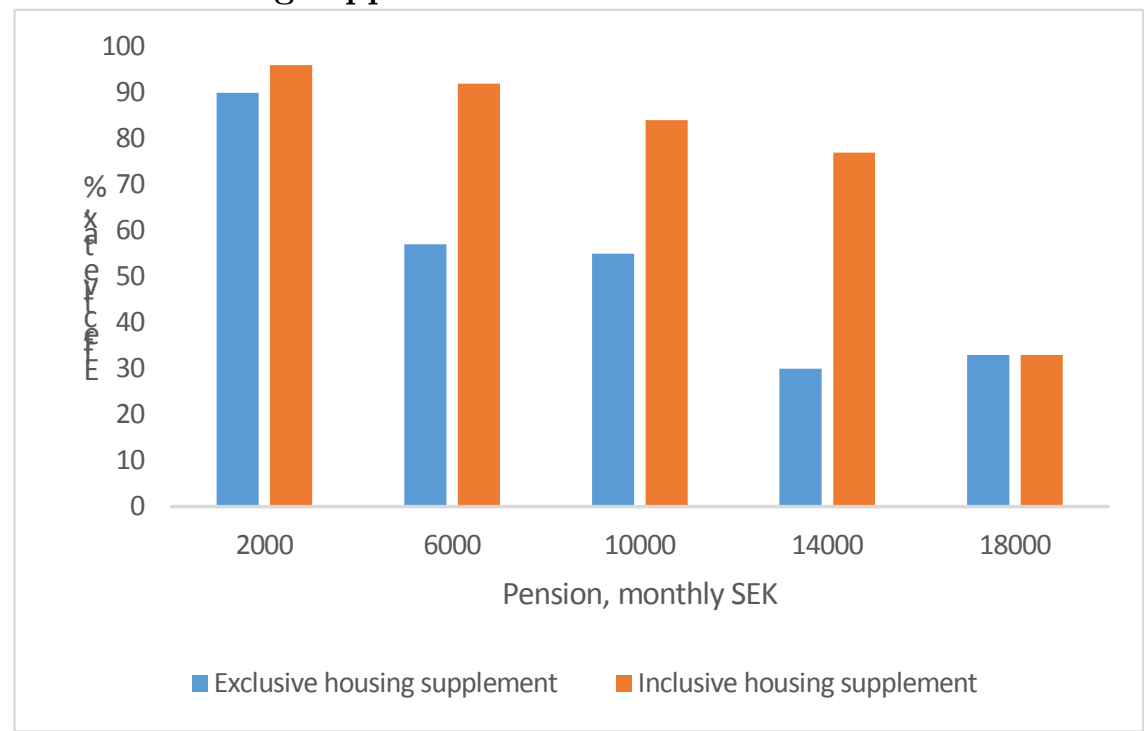

Note: Effective tax rate as depending on the level of private pensions for a single pensioner. Civil servants' pensions are included.

Source: Pensionsmyndigheten (2014)

\section{Macro implications}

As noted in Section 3, the choice of taxation regime (for a given overall tax burden) has crucial implications for public finances. Consider for the sake of argument the schemes $(\mathrm{T}, \mathrm{T} / \mathrm{E}, \mathrm{E})$ and $(\mathrm{E}, \mathrm{T} / \mathrm{E}, \mathrm{T})$ for given tax rates (proportional and equal). For the same levels of saving, the (T,T/E,E) regime front-loads tax revenue and oppositely for $(\mathrm{E}, \mathrm{T} / \mathrm{E}, \mathrm{T})^{28}$. In a setting where pension savings is on an upward increasing trend both due to demographic trends and expansions of mandatory (occupational) pension schemes (as in e.g. both Denmark and Sweden), this has crucial implications.

To illustrate this, Figure 10 shows the development of pension wealth in Denmark. The upward trend reflects the strengthening of pension savings (mainly occupational pensions) and demographic trends. The trend implies intertemporal shifting of tax revenue due to contributions being tax exempt while tax outpayments are taxable income. Hence, roughly $40 \%$ of the pension wealth is deferred taxes. The timing of tax revenue has no implications for fiscal sustainability provided the rate of return on pension savings equals the relevant public discount rate. In practice there may, however, be effects to the extent

\footnotetext{
${ }^{28}$ In a stationary steady-state this would not matter. In a situation with changing demographics with a higher level of contributions than benefits, there is a systematic tendency to postpone tax revenue.
} 
that economic policy responds to the actual budget position. In the building-up phase the budget position is worsened by this taxation regime, and vice versa in the dissavings phase.

Figure 10: Total pension assets, 1984-2012

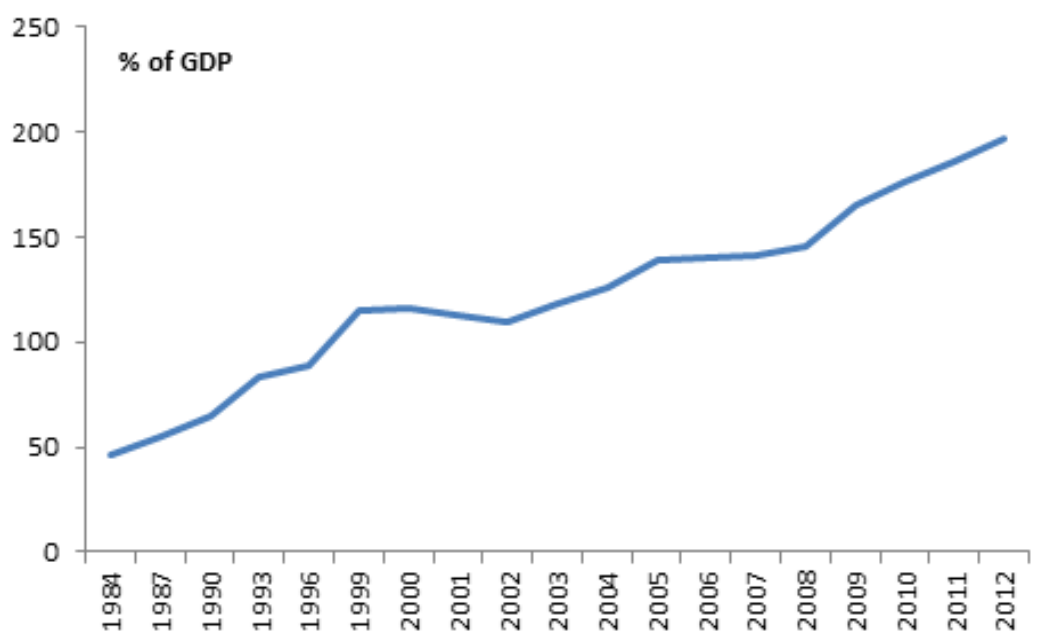

Note: Gross pension wealth in pension funds.

Source: Danish Ministry of Taxation, www.skm.dk

However, there is also a credibility or commitment aspect to the choice of taxation regime. With deferred taxation there is effectively a substantial presaving of public funds which to some extent may match the upward expenditure drift caused by changing demographics. In this way the deferred taxes may be considered as a partial pre-funding of the upward expenditure pressure due to a changing age structure of the population. Whether this is an optimal strategy clearly depends on intergenerational distribution aspects. The temptation under this regime, especially if public finances for other reasons are under pressure, is to front-load some of the tax revenue to improve the current budget position and thus make it possible to meet budget norms. This is not a theoretical discussion as recent Danish experience shows ${ }^{29}$.

Return taxation creates an additional aspect for public finances. Figure 11 shows the revenue from return taxation in Denmark. It is seen that the tax is a significant revenue source, but also that this revenue is rather volatile, reflecting developments in financial market. The return tends to be pro-cyclical, which introduces a pro-cyclical element in the budget on top of the traditional

\footnotetext{
${ }^{29}$ Recently there are some examples of front-loading of tax revenue from pension arrangements. A tax reform in 2012 made it possible to transfer a capital pension into a so-called old age pension with some tax subsidy (2.7\% of the amount transferred). The scheme has later been prolonged to the end of 2015. For the old age pension, there is no tax deductibility at inpayment, but therefore also no tax payment at outpayment, and the outpayment is not subject to means-testing. A similar change (including a tax rebate) was made with the so-called LD pension to front-load tax revenue. Totally about 200 billion DKK in tax revenue have been front-loaded in this way (corresponding to about $20 \%$ of the deferred tax).
} 
automatic stabilizers. However, this does not contribute to stabilization of income and hence demand in the same way as the automatic stabilizers, but it introduces a significant random element in the budget. This may create problems due to budget norms (in particular the budget limit that actual budget deficits cannot exceed $3 \%$ of GDP). It is seen from Figure 11 that volatility in the revenue from pension return taxation in itself may bring the budget from a position in balance to close to the $3 \%$ limit. This is in itself a control problem, but it may also constrain the degrees of freedom for countercyclical policies.

Figure 11: Revenue from taxation of returns in pension funds, $\%$ of GDP, 1984-2014

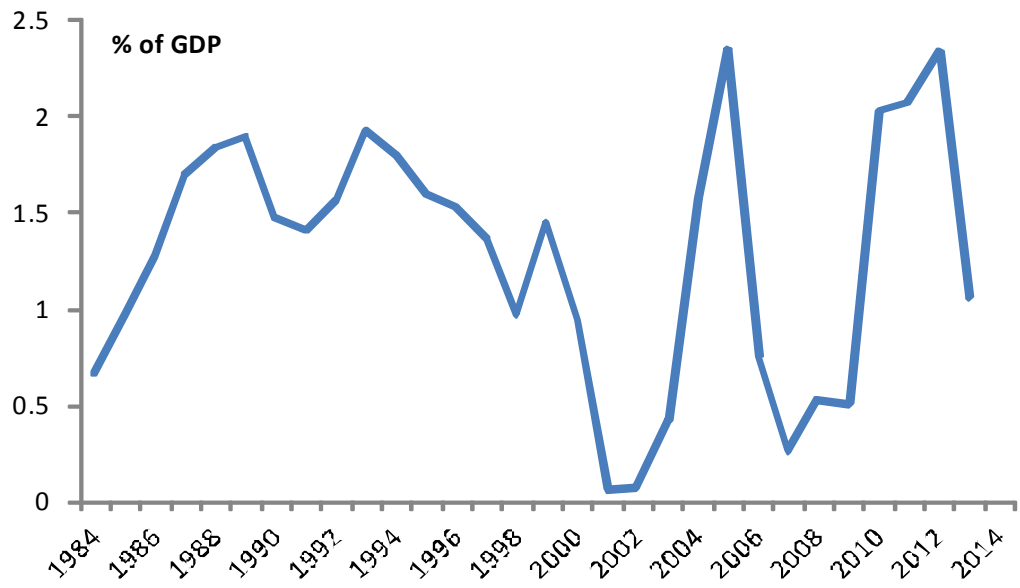

Source: Statistics Denmark.

\section{Concluding remarks}

While pension savings receive favourable tax treatments, both Denmark and Sweden rely on mandatory savings as the key approach to ensure adequate savings levels and thus to reach acceptable replacement rates. In Denmark social partners have taken on the responsibility, implying that occupational pensions are the outcome of bargaining among the labour market organizations, while pension savings is a legal requirement in Sweden. The former system may have the advantage of building on the support of the social partners, but also the problem that the system does not comprise the entire population.

Denmark and Sweden have chosen very different routes in the design of pension systems. Yet, some of the key issues and dilemmas are the same. Both countries have strong distributional objectives, and poverty among pensioners is not accepted. This is reflected in public base/guarantee pensions. To target these pensions to the economically least well-off pensioners, there is means-testing. This also reduces public expenditures to reach these distributional goals, but at the same time it introduces high effective marginal tax rates on savings and retirement decisions. This is a fundamental problem without any perfect solution, 
but it may be questioned whether the marginal tax rates have reached a level where they jeopardize the overall objective of strengthening savings incentives and inducing later retirement (alongside increases in longevity).

Both Denmark and Sweden are basically following an ETT tax regime. While theory implies equivalence to other taxation regimes (for unchanged tax rates), the deferred taxation of pensions implies postponement of tax revenue. It can be seen as pre-funding of future expenditure drifts due to an ageing population, but there is an inherent temptation to front-load revenue. The taxation of return contributes significant revenue, but also substantial volatility in tax revenue when the tax base is current returns as in Denmark, rather than a more smoothed model as in Sweden.

\section{References}

Aaron, H., 1966, The Social Insurance Paradox, Canadian Journal of Economics, 32, 371-4.

Arnberg, S. and M. Barslund, 2012, The Crowding-Out Effect of Mandatory Labour Market Pension Schemes on Private Savings: Evidence from Renters in Denmark, Working Paper 2012:1, Danish Economic Council.

Andersen, T.M., 2015a, Robustness of the Danish Pension System, CESifo DICE Report 2/2015, 25-30.

Andersen, T.M., 2015b, The Danish Pension System - Properties, Outcomes and Challenges, Invited paper for the CLAPES UC Seminar Financiamiento de las Pensiones: Capitalización vs. Reparto, Santiago, Chile, 14 July 2015.

Andersen, T.M. and J. Bhattacharya, 2011, On Myopia as Rationale for Social Security, Economic Theory, 47 (1), 135-158.

Andersen, T.M. and J. Bhattacharya, 2015, Mandatory Pension Saving in a Life-Cycle Perspective, Working Paper.

Andersen, T.M., N. Käättänen and T. Valkonen, 2014, Pension Reforms: Longevity and Retirement, in T. Valkonen and V. Vihriälä, The Nordic Model - Challenged but Capable of Reform, joint with Tema Nord 2014:531.

Bergström, Å.-P. J., M. Palme and M. Persson, 2010, Beskattning af privat pensionssparande, Rapport till Expertgruppen för Studier i Offentlig Ekonomi 2010:2, Finansdepartementet, ESO.

Crawford, V.P. and D.M. Lilien, 1981, Social Security and the Retirement Decision, Quarterly Journal of Economics, 95, 505-529.

Chetty, R., J.N. Friedmand, S. Leth-Petersen, T.H. Nielsen and T. Olsen, 2015, Active vs. Passive Decisions and Crowding-Out in Retirement Savings Accounts: Evidence from Denmark, Quarterly Journal of Economics (to appear).

Cremer, H. and P. Pestieau, 2011, Myopia, Redistribution and Pensions, European Economic Review, 55(2), 165-175.

Danish Economic Council, 2015, Danish Economy - Autumn 2015, Copenhagen.

Diamond, P., 2009, Taxes and Pensions, Southern Economic Journal, 76(1), $2-15$.

Diamond, P. and B. Köszegi, 2003, Quasi-Hyperbolic Discounting and Retirement, Journal of Public Economics, 87, 1839-1872. 
Davidoff, T., J. R. Brown, and P. A. Diamond. 2005. Annuities and Individual Welfare, American Economic Review, 95(5), 1573-1590.

Due, J. and J.S. Madsen, 2003, Fra magtkamp til konsensus - arbejdsmarkedspensionerne og den danske model, DJØFs forlag.

European Commission, 2015, Ageing Report 2015, Brussels.

Feldstein, M., 1985, The Optimal Level of Social Security Benefits, Quarterly Journal of Economics, 100(2), 303-320.

Feldstein, M. and J. Leibman, 2002, Social Security, in Handbook of Public Economics, edited by A. Auerbach and M. Feldstein, Vol. 4, Chapter 32, Elsevier.

Fehr, H. and J. Uhde, 2015, Means-Testing Retirement Benefits in the UK: Is it Efficient?, Working Paper.

Findley, T.S. and F.N. Caliendo, 2012, Time Inconsistency and Retirement Choice, Working Paper.

Garon, J.-D., 2012, Self-Control, Commitment and Redistributive Public Pensions, Working Paper.

Isaksen, J., P.L. Kramp, L.F. Sørensen and S.V. Sørensen, 2011, Husholdningernes balancer og gæld - et internationalt landestudie (Household Balances and Debt - An International Country Study), Nationalbankens Kvartalsoversigt, 4. kvartal, Del 1.

Kaplow, L., 2015, Myopia and the Effects of Social Security and Capital Taxation on Labor Supply, National Tax Journal, 68(1), 7-32.

Krusell, P., B. Kuruscu, and A.A. Smith, Jr., 2010, Temptation and Taxation, Econometrica, 78(6), 2063-2084.

Laibson, D., 1996, Hyperbolic Discount Functions, Undersaving, and Savings Policy, NBER Working Paper No. 5635. National Bureau of Economic Research, Cambridge, MA.

Mercer, 2015, The Melbourne Mercer Global Pension Index.

Money and Pension Panel Expert Group, 2012, Basic Pensions -The Default Option for Labour-Market Pensions, Report by the Committee of the Money and Pension Panel, Copenhagen.

Ministry of Finance, 2015, Convergence Programme Denmark 2015, Copenhagen.

OECD, 2014, Pensions at a Glance, Paris.

OECD, 2014, Economic Survey - Sweden, Paris.

Palmer, E., 2000, The Swedish Pension Reform Model: Framework and Issues, Social Protection Paper 12, World Bank, Washington.

Pensionskommissionen, 2015, The Danish Pension System - Internationally Praised but not without Problems (Det danske pensionssystem - international anerkendt, men ikke problemfrit), Copenhagen.

Pensionsmyndigheten, 2011, Det svenska pensionssystemet, Stockholm.

Pensionsmyndigheten, 2014, Från fattigvård till ekonomisk trygghet vid ålderdom - beskrivning af grundskyddet i det svenska pensionssystemet, Stockholm.

Pestieau, P. and U.M. Possen, 2008, Prodigality and Myopia: Two Rationales for Social Security. Manchester School 76(6), 629-52. 
St-Amant, P.-A.B, and J.-D. Garon, 2014, Optimal Redistributive Pensions and the Costs of Self-Control, International Tax and Public Finance.

Sørensen, P.B., 2010, Dual Income Taxes: A Nordic System, In I. Claus, N. Gemmell, M. Harding and D. White (eds.), Tax reform in Open Economies, Edwar Elgar.

Yoo, K.-Y. and A. de Serres, 2004, Tax Treatment of Private Pension Savings in OECD Countries, OECD Economic Studies, 39, 73-110.

World Bank, 1994, Averting the Old Age Crisis, World Bank Publications, Washington D.C.

Økonomi- og Indenrigsministeriet, 2015, Familiernes $\varnothing$ konomi - fordeling, fattigdom og incitamenter, Copenhagen. 


\section{Appendix}

Consider a stylized version of the standard life-cycle model of consumption and work choice (hours and retirement). Time is continuous, and the representative household has a deterministic life-time $T$, working for the first $R$ years and then retiring (retirement period $=T-R$ ).

The individual faces the following tax-pension scheme: Labour income is taxed at the rate $\tau_{y}$, contributions to funded pension schemes are deductible in labour income at the rate $\tau_{d}$, while the benefits are taxed at the rate $\tau_{p}$. Return on pension savings is taxed at the rate $\tau_{r}$. All tax rates belong to the interval $[0,1[$. When retired the individual is entitled to a public pension $b$ which is means-tested against private pensions (wealth) at the tapering rate ${ }^{30}$ $m \in[0,1[$.

Life-time utility is given as

$$
\Omega=\int_{0}^{R} e^{-\rho t} u\left(c_{t}, h_{t}\right) d t+\int_{R}^{T} e^{-\rho t} v\left(c_{t}\right) d t
$$

where $u(\cdot)$ and $v(\cdot)$ are utility functions when working and retired, respectively. The utility functions satisfy all the standard properties.

The life-time utility $(\Omega)$ is maximized subject to the constraint that the present value of consumption when working and saving for retirement is equal the present value of labour income (initial wealth equal to zero, to simplify), i.e.

$$
\int_{0}^{R} e^{-\widehat{r} t} c_{t} d t+\left(1-\tau^{d}\right) \int_{0}^{R} e^{-\widehat{r} t} s_{t}^{p} d t=\left(1-\tau_{y}\right) \int_{0}^{R} e^{-\widehat{r} t} w_{t} h_{t} d t
$$

where $^{31}$

$$
\widehat{r}=r\left(1-\tau_{r}\right)
$$

and that the present value of consumption when retired equals pension wealth $\left(W_{p}\right)$ at retirement and the present value of the public pension, i.e.

$$
\int_{R}^{T} e^{-\widehat{r}(R-t)} c_{t} d t=\int_{R}^{T} e^{-\widehat{r}(R-t)} b d t+W_{p}
$$

where

$$
W_{p} \equiv(1-m)\left(1-\tau^{s}\right) \int_{0}^{R} e^{\widehat{r}(R-t)} s_{t}^{p} d t
$$

Note that means-testing on the basis of the pension wealth $\left(W_{p}\right)$ at retirement or private pension outpayments makes no difference (for a constant tapering rate). Denoting the Lagrange-multipliers associated with the two constraints by $\lambda$

\footnotetext{
${ }^{30}$ For tractability the non-negative constraint on public pensions is disregarded. The expressions below can be interpreted to hold when the non-negative constraint is not binding, and when it is binding the expression can be interpreted with $m=0$.

${ }^{31}$ In the deterministic setting it is not possible to make a distinction between general capital income taxation and taxation on pension savings since this will leave arbitrage possibilities if capital markets are complete. Introducing capital market imperfections will complicate the analysis considerably.
} 
and $\eta$, respectively, we have that the Lagrangian associated with the household maximization problem reads

$$
\begin{aligned}
\Psi= & \int_{0}^{R} e^{-\rho t} u\left(c_{t}, h_{t}\right) d t+\int_{R}^{T} e^{-\rho t} v\left(c_{t}\right) d t \\
-\lambda & {\left[\int_{0}^{R} e^{-\widehat{r} t} c_{t} d t+\left(1-\tau^{d}\right) \int_{0}^{R} e^{-\widehat{r} t} s_{t}^{p} d t-\left(1-\tau_{y}\right) \int_{0}^{R} e^{-\widehat{r} t} w_{t} h_{t} d t\right] } \\
-\eta & {\left[\int_{R}^{T} e^{-\widehat{r}(R-t)} c_{t} d t-\int_{R}^{T} e^{-\widehat{r}(R-t)} b d t-(1-m)\left(1-\tau^{s}\right) \int_{0}^{R} e^{\widehat{r}(R-t)} s_{t}^{p} d t\right] }
\end{aligned}
$$

The first-order conditions for consumption when working and retired, respectively, are given as

$$
\begin{aligned}
e^{-\rho t} u_{c}\left(c_{t}, h_{t}\right) & =\lambda e^{-\widehat{r} t}, \text { for } t<R \\
e^{-\rho t} v_{c}\left(c_{t}\right) & =\eta e^{-\widehat{r}(R-t)}, \text { for } t>R
\end{aligned}
$$

implying that the ratio between the subjective $(\rho)$ and objective discount rate $(\widehat{r})$ determines the consumption profile when working and when retired.

The first order-condition for working hours reads

$$
e^{-\rho t} u_{h}\left(c_{t}, h_{t}\right)=-\lambda\left(1-\tau_{y}\right) e^{-\widehat{r} t} w_{t}
$$

or by use of $(1)\left(\right.$ recall $\left.u_{h}(\cdot)<0\right)$

$$
\frac{u_{h}\left(c_{t}, h_{t}\right)}{u_{c}\left(c_{t}, h_{t}\right)}=-\left(1-\tau_{y}\right) w_{t}
$$

which is the standard condition for determination of labour supply along the intensive margin.

The first order condition for pension savings in any period $t(<R) s_{t}^{p}$ is

$$
\lambda e^{-\widehat{r} t}\left(1-\tau^{d}\right)=\eta e^{-\widehat{r}(R-t)}(1-m)\left(1-\tau^{s}\right)
$$

implying that

$$
\frac{\lambda}{\eta e^{\widehat{r} R}}=\frac{(1-m)\left(1-\tau^{s}\right)}{\left(1-\tau^{d}\right)}
$$

Note also that

$$
\begin{aligned}
\frac{u_{c}\left(c_{R}, h_{R}\right)}{v_{c}\left(\widetilde{c}_{R}\right)} & =\frac{\lambda}{\eta} e^{-\widehat{r} R} \\
& =\frac{(1-m)\left(1-\tau^{s}\right)}{\left(1-\tau^{d}\right)}
\end{aligned}
$$

Hence, if $\frac{(1-m)\left(1-\tau^{s}\right)}{\left(1-\tau^{d}\right)}<1$, it follows that $u_{c}\left(c_{R}, h_{R}\right)<v_{c}\left(\widetilde{c}_{R}\right)$; i.e. the marginal value of consumption when working is lower than the marginal value of 
consumption when retired. To see the implications more clearly, assume separable preferences, $u(c, h)=v(c)-\varphi(h)$ in which case $\frac{v_{c}\left(c_{R}\right)}{v_{c}\left(\bar{c}_{R}\right)}=\frac{(1-m)\left(1-\tau^{s}\right)}{\left(1-\tau^{d}\right)}$. If $\frac{(1-m)\left(1-\tau^{s}\right)}{\left(1-\tau^{d}\right)}<1$, we have $v_{c}\left(c_{R}\right)<v_{c}\left(\widetilde{c}_{R}\right)$, implying $c_{R}>\widetilde{c}_{R}$. Hence, for $\frac{(1-m)\left(1-\tau^{s}\right)}{\left(1-\tau^{d}\right)}<1$ there is a discrete downward jump in consumption at retirement.

The first-order condition for the retirement age is

$$
\begin{aligned}
e^{-\rho R} u\left(c_{R}, h_{R}\right)-e^{-\rho R} v\left(\widetilde{c}_{R}\right)= & \lambda e^{-\widehat{r} R}\left[c_{R}+\left(1-\tau^{d}\right) s_{R}^{p}-\left(1-\tau_{y}\right) w_{R} h_{R}\right] \\
& +\eta\left[-\left[\widetilde{c}_{R}-b\right]-(1-m)\left(1-\tau^{s}\right) s_{R}^{p}\right] \\
= & \lambda e^{-\widehat{r} R}\left[c_{R}+\left(1-\tau^{d}\right) s_{R}^{p}-\left(1-\tau_{y}\right) w_{R} h_{R}\right] \\
& +\lambda e^{-\widehat{r} R} \frac{\left(1-\tau^{d}\right)}{(1-m)\left(1-\tau^{s}\right)}\left[-\left[\widetilde{c}_{R}-b\right]-(1-m)\left(1-\tau^{s}\right) s_{R}^{p}\right]
\end{aligned}
$$

or by use of (4) as

$e^{-\rho R}\left[u\left(c_{R}, h_{R}\right)-v\left(\widetilde{c}_{R}\right)\right]=\lambda e^{-\widehat{r} R}\left[-\left(\widetilde{c}_{R}-b\right) \frac{\left(1-\tau^{d}\right)}{(1-m)\left(1-\tau^{s}\right)}+c_{R}-\left(1-\tau_{y}\right) w_{R} h_{R}\right]$

or by use of (1) and rearranging

$$
\left[u\left(c_{R}, h_{R}\right)-v\left(\widetilde{c}_{R}\right)\right]=u_{c}\left(c_{R}, h_{R}\right)\left[\left(\widetilde{c}_{R}-b\right) \frac{\left(1-\tau^{d}\right)}{(1-m)\left(1-\tau^{s}\right)}-c_{R}-\left(1-\tau_{y}\right) w_{R} h_{R}\right]
$$

which can be written

$\left[v\left(\widetilde{c}_{R}\right)-u\left(c_{R}, h_{R}\right)\right]=u_{c}\left(c_{R}, h_{R}\right)\left[\left(1-\tau_{y}\right) w_{R} h_{R}-\frac{\left(1-\tau^{d}\right)}{(1-m)\left(1-\tau^{s}\right)} b+\widetilde{c}_{R} \frac{\left(1-\tau^{d}\right)}{(1-m)\left(1-\tau^{s}\right)}-c_{R}\right]$

The condition says that the optimal retirement age $(R)$ is the age at which the utility gain from retiring (LHS) equals the marginal costs (RHS). The latter is the sum of the gain from work and the effect of changes in consumption upon retirement, all weighted by the marginal utility of consumption. Note that the retirement decision does not depend directly on pension wealth (drops out due to the envelope theorem).

The term $\widetilde{c}_{R} \frac{\left(1-\tau^{d}\right)}{(1-m)\left(1-\tau^{s}\right)}-c_{R}$ captures that upon retirement there is a discrete change in consumption (cf. above) and that one unit of consumption when working translates into $\frac{(1-m)\left(1-\tau^{s}\right)}{\left(1-\tau^{d}\right)}$ units of consumption when retired. If preferences are separable, it follows that $\widetilde{c}_{R} \frac{\left(1-\tau^{d}\right)}{(1-m)\left(1-\tau^{s}\right)}-c_{R}>0$ for $\frac{(1-m)\left(1-\tau^{s}\right)}{\left(1-\tau^{d}\right)}>1$; i.e. this effect adds to the costs of retirement.

Notice that for $\widetilde{c}_{R} \frac{\left(1-\tau^{d}\right)}{(1-m)\left(1-\tau^{s}\right)}=c_{R}$ the condition for the optimal retirement age reads

$$
\left[v\left(c_{R}\right)-u\left(c_{R}, h_{R}\right)\right]=u_{c}\left(c_{R}, h_{R}\right)\left[\left(1-\tau_{y}\right) w_{R} h_{R}-\frac{\left(1-\tau^{d}\right)}{(1-m)\left(1-\tau^{s}\right)} b\right]
$$


i.e. the optimal retirement age is when the utility gain from more leisure (LHS) equals the marginal utility value of postponing retirement (weighted by the appropriate discount rates). Notice this is the same determination of retirement as in Crawford and Lilien (1981) ${ }^{32}$.

The value at retirement of pension savings made at time $t$ is

$$
V(r, t)=e^{\widehat{r}(R-t)} \frac{(1-m)\left(1-\tau^{s}\right)}{\left(1-\tau^{d}\right)}
$$

in the absence of any forms of taxation and means-testing it would be

$$
V^{*}(r, t)=e^{r(R-t)}
$$

A measure of the tax burden is

$$
\frac{V(r, t)}{V^{*}(r, t)}
$$

i.e. the reduction in the value of savings relative to the no-tax case. It follows that

$$
\frac{V(r, t)}{V^{*}(r, t)}=e^{(\widehat{r}-r)(R-t)} \frac{(1-m)\left(1-\tau^{s}\right)}{\left(1-\tau^{d}\right)}
$$

where

$$
\frac{\partial}{\partial t}\left[\frac{V(r, t)}{V^{*}(r, t)}\right]=-(\widehat{r}-r) \frac{(1-m)\left(1-\tau^{s}\right)}{\left(1-\tau^{d}\right)}
$$

i.e. if $\widehat{r}-r>0$, it follows that the closer to retirement pension savings is made, the larger the implicit tax. Pension savings close to retirement is not as attractive as savings when young!

\footnotetext{
${ }^{32}$ Which has $\frac{(1-m)\left(1-\tau^{s}\right)}{\left(1-\tau^{d}\right)}=1$ and $c_{R}=\widetilde{c}_{R}$.
} 